\title{
MIR30C1 Gene
}

National Cancer Institute

\section{Source}

National Cancer Institute. MIR30C1 Gene. NCI Thesaurus. Code C162382.

This gene may be involved in the modulation of gene expression during wound healing and angiogenesis. 